\title{
Employee Absence Management in Modern Organization
}

\author{
Joanna Gajda \\ Czestochowa University of Technology, Częstochowa, Poland
}

\begin{abstract}
Recent years have resulted in modernizing the organization of work, and development of management methods aimed at looking for opportunities to unleash the inherent potential of the people. It is worth mentioning that a very important new area of research was developed - managing employee absences. Employers are often calculating the cost of employee absence and they take specific actions to implement the prevention program. The aim of this paper is to present, based on the analysis of literature, solutions targeted on effectively managing employee absences. Considerations have been divided into three parts. The first part focuses on defining the term "absence". The second part is about analysis of the costs faced by the organization. The third part is devoted to ways of reducing the level of absences from work.
\end{abstract}

Keywords: absences, the costs of absenteeism, absence management

The economic recovery, that has been taking place for many years, had a significant influence on the change in the approach to human resources management. It is clearly moving toward an increase in the effectiveness of dealing with personnel issues. One of the important issues, which many companies face, is employee absenteeism and skillful management of this phenomenon. Employee absenteeism negatively affects the stability of the organization. Sick leaves bring huge losses to companies. Employers that are aware of this fact more often estimate the costs of employee absenteeism and seek solutions for an improvement. The problem of absenteeism management is one of the new areas of decision-making in organizations in Poland. Those that implement innovative solutions in the field of human resource management use the possibility of reducing the level of employee absenteeism and appreciate the savings achieved thanks to these solutions.

The purpose of this paper is to present, basing on the literature, the causes leading to the occurrence of employee absence, irregularities in the sphere of human resource management at the organization level. It also attempts to identify opportunities to use absence management process to prevent destructive factors influencing the level of employee absence. Although the author does not give a detailed analysis and thorough description of the individual issues, some of the proposed methods and solutions are universal enough, so that they can be a contribution to further research.

\section{The Definition of Employee Absence}

W. Cascio understands the term employee absence as absence of staff of the organization in the workplace (Śmid, 2000). Employee absenteeism takes place when an employee does not show up for work or leaves his current workplace. The absence of employee can be justified or not (Cascio, 2001). There are two kinds of absences - planned and unplanned. The reasons for planned absence include: annual leave (holiday, force

Corresponding author: Joanna Gajda, Ph.D., Czestochowa University of Technology, Częstochowa, Poland; research field: management of the organization. E-mail: joannagajda@vp.pl. 
majeure leave, parental leave), delegations, and business trips. Even in such situation, the employee is expected to notify the employer of the planned absence in advance. Among the reasons of unplanned employee absences are: illness of the employee or his family member, important family or administrative matters, accidents on the way to work, and events that are out of the employee's control. This category includes unjustified absence from work (Gajdzik, 2013).

According to Schaufeli and his colleagues, the general prosperity of the organization can affect the level of employee absenteeism. They noted that having high requirements of subordinates' work quality can cause adverse effects, such as: work overload, time pressure, imbalance between work and personal life, which consequently leads to a professional burnout and causes additional absences.

Research conducted in Poland by the Institute of Occupational Medicine shows that the risk of absence from work is a reflection of disturbances occurring in the social environment at work, such as: negative attitudes toward work, poor cooperation, that contribute to increasing the level of job stress and have a direct impact on the changes in the health of workers (Szubert, Merecz-Kot, \& Sobala, 2009).

\section{The Costs of Absenteeism}

The costs incurred by organizations and the general public are related to employee absenteeism. As shown by numerous academic studies, absenteeism's costs incurred by organizations are very high. They include, among others: pay for substitution and overtime, which result from the need to carry out the tasks at the workplace in place of employees who are on a sick leave. However, employers are often unaware of how big indirect costs of absenteeism are. They include: administrative costs of dismissal, costs arising because of recruitment and training of new staff, costs arising from delays in production, related to issues with contracts, low quality and efficiency of work carried out by inexperienced workers or working overtime while substituting for employees on sick leave (Pęcłło, 2013). The costs of absenteeism are also incurred by the general public, and among them are: the cost of health care, sickness benefit payments, and the loss of tax revenue. The costs are also incurred by customers remaining in direct relationship with the company and are usually associated with failure to meet deadlines and poor quality of services.

\section{Employee Absence Management}

Absence management is a continuous process intended to reduce the level of absenteeism. It is implemented by a coordinating group, which deals with the management of individual jobs. The team consists of HR (human resources) staff which deals with absence record-keeping, finance department staff, whose role is limited to accounting of employee absenteeism, inspectors for safety and health at work, direct managers, team leaders and, in some cases, occupational physicians and psychologists (Gajdzik, 2015). Table 1 presents the activities related to the management of absences along with their executors.

Some of the researchers put emphasis on employee absence analysis, because they assume that the rate of absences at workplace is the result of commitment and motivation which can be the basis to determine the value of human capital (Striker, 2013). The main factor which determines the effectiveness of solving the problems of absenteeism is to have full information on the issue. Thus, it is necessary for the organization to have adequate data on the number of days when employee was absent from work, and to identify the rate and direct costs of absenteeism so that the absence management policy can be successful ${ }^{1}$.

${ }^{1}$ Retrieved from http://archiwum.nf.pl/19896-poziom-absencji-w-pracy-rosnie-jak-zarzadzac-tym-zjawiskiem/. 
Table 1

\section{Examples of Activities in the Management of Absences and Their Executors/Coordinators}

\begin{tabular}{|l|l|}
\hline $\begin{array}{l}\text { Setting objectives for absenteeism management programs and } \\
\text { an acceptable level of absenteeism rate }\end{array}$ & $\begin{array}{l}\text { Human resources department in cooperation with the } \\
\text { managerial staff and with the support of middle-level } \\
\text { organizations }\end{array}$ \\
\hline $\begin{array}{l}\text { Identifying the causes of absenteeism and linking them to the } \\
\text { place and the way of working }\end{array}$ & $\begin{array}{l}\text { Human resources department in cooperation with occupational } \\
\text { health and safety professionals and managers }\end{array}$ \\
\hline $\begin{array}{l}\text { Corrective actions in organizing work in case of employee } \\
\text { absence }\end{array}$ & Team leaders, managers of middle and lowest level organization \\
\hline $\begin{array}{l}\text { The possibility of carrying out medical checkups on other day } \\
\text { than the one fixed previously }\end{array}$ & $\begin{array}{l}\text { Human resources department in cooperation with occupational } \\
\text { physicians and immediate supervisors of employees }\end{array}$ \\
\hline $\begin{array}{l}\text { Additional medical examinations and consultations with doctors } \\
\text { as part of preventive health care }\end{array}$ & $\begin{array}{l}\text { Human resources department in cooperation with physicians, } \\
\text { analytical laboratories' employees, therapists, psychologists }\end{array}$ \\
\hline Verification of proper usage of sick leaves & Personnel department in accordance with established procedure \\
\hline Monitoring annual absence rates & $\begin{array}{l}\text { Human resources department in cooperation with financial } \\
\text { department }\end{array}$ \\
\hline Rewarding for perfect attendance & $\begin{array}{l}\text { Distribution of bonus fund is the responsibility of the director } \\
\text { general, the payment of awards is the task of finance department } \\
\text { in cooperation with human resources department }\end{array}$ \\
\hline $\begin{array}{l}\text { Training and interviews with employees to find ways to solve } \\
\text { the causes of absenteeism }\end{array}$ & Health and safety, HR \\
\hline $\begin{array}{l}\text { Interviews with employees coming back to work after a long } \\
\text { absence }\end{array}$ & Human resources department, managers, and team leaders \\
\hline Improvement of work conditions and safety & $\begin{array}{l}\text { Health and safety inspector, investment department, } \\
\text { maintenance services, and technical services }\end{array}$ \\
\hline
\end{tabular}

Note. Source: Gajdzik (2015, p. 47).

This information can be used to:

(1) Understand the causes of absences, identify trends and patterns on how employees use the leave;

(2) Focus on actions against employees who have the highest level of absences;

(3) Establish procedures of human resource management in response to the analysis of the history of absence of employees;

(4) In order to provide feedback to employees;

(5) Estimate the benefits of implementing an absence management strategy;

(6) Estimate the costs of absenteeism;

(7) Usage of external and internal benchmarking in assessing the level of absences ${ }^{2}$.

It is recommended for organizations to develop a program to reduce the level of absenteeism. This program should include:

(1) Analysis of working conditions and attitude toward non-employees who were on a sick leave;

(2) Inspections to verify employees' attitude toward their assigned tasks and executives;

(3) Anonymous surveys in which employees have an opportunity to express their opinion on the problematic issues, which can be a foundation of a program that contributes to the improvement of working conditions and minimizing absenteeism ${ }^{3}$.

2 Retrieved from http://www.cipd.co.uk_NR_rdonlyres_3A208F80-3484-4CE7-B8DD-907FFE660850_0_Wellbeing_sample_ chapter 02 .

${ }^{3}$ Retrieved from http://workservicewroc.blogspot.com. 
Usually the current situation is thoroughly analyzed before the implementation of the process of absence management. This is a preliminary stage during which the attendance of employees is controlled and timesheets are analyzed to determine the number of absences of employees. In addition to controlling the timesheets, the costs of absenteeism are calculated (Gajdzik, 2014). To estimate the costs of absenteeism, the company estimates direct costs, which are found in payroll and accounting documents, and indirect costs, which are measured by using complex methods of measurement. Financial department of the organization is responsible for providing information about the actual costs. Calculation of indirect costs is a long process. Quite often, specialists outside the company are hired to identify the categories and amount of indirect costs associated with employee absenteeism.

As business practice shows, organizations seeking to minimize unplanned absences tend to focus on determining an acceptable annual absenteeism rate based on the following formulas (Gajdzik, 2015):

$$
\begin{gathered}
\sum \frac{\text { Total number of days lost through job absence }}{\text { Average number of employees }} \times \text { Number of available workdays } \\
\frac{\text { Total number of sick days (without maternity leave and accidents) }}{\text { Nominal number of man-days }} \\
\frac{\text { Total number of hours not worked }}{\text { Total number of working hours }}
\end{gathered}
$$

When an employer has chosen to minimize the overall level of absence from the workplace for any reason, he can use the Formula (1). If he wants to limit the absenteeism caused by sick leave, it is reasonable to use the second formula. The intention of the employer should not be to question the sickness certificates to which employees are entitled, but to reduce absenteeism by encouraging use medical certificates fairly.

After approving the acceptable absenteeism rate and determining the objectives of absence management program, detailed solutions to minimize the number of unplanned employee absences are set. Human resources management is dominated by the traditional approach to the analysis of employee absence where a questionnaire and time or attendance systems are used. This kind of research is looking for a correlation between such variables as demographic rate (age, gender, work experience, and education), responses from questionnaire and absenteeism rate. This method aims to determine the relationship between such elements as: absence from work, motivation, and job satisfaction. In management practice, comparative test between diverse groups are used. They provide an opportunity to check the differences of the point of view of managers and subordinates on issues related to absenteeism. Absence management practice shows that in-depth interviews and observation are a valuable source of theoretical knowledge.

In studies conducted on absenteeism measurement, the source of information can be a conversation with the employee which helps to better identify causes of absence from work. M. Striker, however, draws attention to the fact that the data collected during interview are sensitive and access to them is possible only thanks to the good will of the employee. Minimal scope of collected information on absences suggested by the author is included in Table 2.

It should be noted that the cause of absence appears here three times - the preliminary cause of absence, the formal cause indicated in the documentation, and the reason given during a direct conversation with the manager. 
In order to reduce absenteeism, it is important to specify the conditions of organizational culture based on values such as loyalty, honesty, professionalism, openness, integrity, credibility, and respect for another human being. Listed values affect the formation of new relationships within the organization and organizational structures which are based on employee's legal and subjective responsibility. For the functioning of this kind of responsibility, it is essential to develop internal guide which is a collection of best practices. Their observance is changing the attitudes and responsibility for efficient utilization of working time. It should be noted that it is worthwhile to transfer certain powers from the executive levels to subordinates, expanding their scope of decision-making because doing so will help them accept responsibility for the tasks in their workplace (Gajdzik, 2015).

A lot of absences are caused by the stress experienced by workers which is a result of a tense atmosphere at work (Szubert et al., 2009). Presence of stress in the workplace is enhanced by factors resulting from an improperly designed workstation and improper organization. Irregularities can occur in areas that are important from the employee's point of view. Those areas are presented in the table below (see Table 3 ).

Table 2

The Minimal Scope of Collected Information on Absences

\begin{tabular}{|l|}
\hline After the start of absence: \\
\hline Name, position, department, age, gender \\
\hline Date of the first day of absence \\
\hline Date of expected return to work \\
\hline Preliminary cause of absence \\
\hline Determining whether the absence is related to working conditions \\
\hline Determining whether the absence is justified \\
\hline After the end of absence: \\
\hline Date of the last day of absence \\
\hline Number of days or hours of absence \\
\hline Formal cause of absence \\
\hline Cause of absence specified during the meeting with the direct superior after returning to work \\
\hline
\end{tabular}

Note. Source: Striker (2013, pp. 99-112).

Table 3

Irregularities (Related to) in Important Areas for the Employee

\begin{tabular}{|l|l|}
\hline The area of influence & Low level of control over the work environment, organization of work, way of performing work \\
\hline The area of support & $\begin{array}{l}\text { Lack of help and support from superiors, lack of praise and encouragement, lack of a trusted } \\
\text { person with whom an employee can talk about fears and emotions, lack of support from } \\
\text { colleagues }\end{array}$ \\
\hline The area of requirements & $\begin{array}{l}\text { Too much work or too fast pace of work, underload and overload of work, type of work or } \\
\text { mismatched position, too monotonous activities to give satisfaction }\end{array}$ \\
\hline The area of relationships & $\begin{array}{l}\text { Lack of respect from supervisor or co-workers, harassment and insults, conflicts, poor } \\
\text { management style }\end{array}$ \\
\hline The area of professional role & $\begin{array}{l}\text { Lack of clearly specified responsibilities, goals and evaluation criteria, lack of skills, many } \\
\text { conflicting orders from supervisor }\end{array}$ \\
\hline The area of security & $\begin{array}{l}\text { Low guarantee of employment, pay disparity, disturbed balance between personal and } \\
\text { professional live, unfair treatment during distribution of responsibilities and during selection } \\
\text { process, falsified communication in the company (lying, concealing the truth) }\end{array}$ \\
\hline
\end{tabular}

Note. Source: Kowalska-Jarnot (2015). 
As the table shows, situation of the employee in the company has an impact on individual reactions to stress. Therefore, it seems necessary to control and reduce the risks underlying both the organization itself and employees. A major challenge for business owners is preventive actions which include (Kowalska-Jarnot, 2015):

(1) Raising awareness of health prevention and ways of dealing with stress;

(2) Psychological workshops strengthening psychical resistance and ability of self-management;

(3) Training of executives and managers in building a friendly working environment;

(4) A system to capture and punish discriminatory actions;

(5) Identification of high-risk positions and creation of a special system of staff support.

It is worth noting that preventive actions are associated with benefits for both employees and employers. Therefore, the responsibility of executives should be to reduce the risks and increase safety in the workplace, but the law also imposes this obligation on employees. In order to implement the standards of safety and quality of work, business owner should enable the employees to participate in preventive measures, which would increase the level of knowledge of possible dangers. Preventive measures can result not only in reduction of costs of absences or improvement of conditions and quality of work, but can also help in raising the level of competitiveness of the company (Rzepecki, 2006).

An important step toward the reduction of absences is to teach subordinates how to cope with pressure (Bodzioch, 2014). The organization should encourage employees to participate in various forms of training that will benefit them (Bodzioch, 2014). It is important to enable them to acquire knowledge in shaping appropriate attitudes which will help them to avoid disciplinary action such as: reprimand, warning, reduction in salary, and dismissal due to unexcused absences.

It is also important to strengthen motivation which will help in engaging employees in performing their duties so that they will reluctantly leave their workplace. Organizations should avoid the usage of penalties for absence in favor of rewards for attendance. They do not always have to be in form of a bonus. It is important that the employee feels that he is appreciated. An effective way to reduce employee absenteeism is the usage of incentive programs. Their goal is to increase job satisfaction and thus increase the efficiency of employees. Companies are increasingly turning to the introduction of bonuses for employees, whose costs are incurred by customers. In the process of concluding a trade agreement, some companies fix a bonus fund ${ }^{4}$.

To avoid an increase of unplanned absences, organizations appreciate the possibility to introduce flexible working hours, which enable to work remotely from home $\mathrm{e}^{5}$. One of the prerequisites for flexibility is the different types of contracts. Usually companies want to maintain the right balance between indefinite and temporary contracts (probationary period, fixed term, temporary work) (Lis, 2015).

Progressive companies that are facing many problems caused by employee absenteeism opt for innovative solutions, such as hiring people from temporary employment agencies. The worker is recruited by the agency and his duties are performed for another employer ${ }^{6}$. Depending on the needs, it is possible to hire workers for one day or even several months. It is a really good solution because they can be hired not only in crisis situations, but as a way to reduce the costs associated with the functioning of the company. Outsourcing process is also used, which means that agency assumes an obligation for the transfer of employees, but most of

\footnotetext{
${ }^{4}$ Retrieved from http://www.BiznesNabieraDynamiki.pl.

5 Retrieved from http://www.hrtrendy.pl.

${ }^{6}$ Retrieved from http://www. Ihrpolska.pl .
} 
all for a specific portion of this process (Ochremiak, 2015). Today, modern personnel management tool that allows to relieve the managers from dealing with personal problems of subordinates is the Employees Assistance Program. It allows employees to rely on the professional support of the consultant from which both the employee and the company benefits - employee returns to work faster, costs of absence are reduced, rotation of employees is also reduced, which is directly associated with reduction in expenditures for the recruitment and training ${ }^{7}$.

\section{Conclusions}

Every employer must take into account the risk of employee absences. But to maintain satisfactory work efficiency, reduce the high costs incurred due to the absence of workers, he should take reasonable steps leading to lowering the level of absences. It aims to introduce clear absence policy aimed at accurate measurement of absenteeism, capable of providing data at its level and identifying its reasons, determining the costs of absenteeism and defining the acceptable number of absences and the consequences of failing to meet them. It is important to develop strategies to effectively support these areas and to encourage workers to return to the company and to increase the efficiency and productivity of individuals. Currently, the managers are required to assess the validity of usage of absence management tools and select those that can be adapted to the specific situation.

Analysis of the literature leads to the conclusion that the first priority for researchers of this problem is the access to information about human resources. The quality of information available to the management team is doubtful. Because of gaps occurring in knowledge about the attributes relating to the processing of information about human resources, they are not seen as useful in decision-making process. In a study of absenteeism, it can be seen that although this phenomenon is easy to measure, in practice, it is rarely monitored. Due to the fact that absenteeism is a source of measurement of human capital value, it cannot be ignored in explaining its complexity and determining the value of human capital. The results of the research in this field are important for the effectiveness of future actions aimed at reduction of the size of this phenomenon.

\section{References}

Bodzioch, K. (2014). Management of employee absenteeism. Retrieved from http://hrstandard.p1/2011/09/29/zarzadzanieabsencja-pracownikow/

Cascio, W. (2001). Calculation of human resources costs (p. 10). Cracow: ABC Publishing House, Economics Publishing House.

Cost cutting HR-How to optimize costs in the company without employment reduction. (2001). Retrieved from http://www.BiznesNabieraDynamiki.pl.

Gajdzik, B. (2013). Policy of reducing the absences due to accidents in a manufacturing company. Zarzadzanie Przedsiębiorstwem, 16(4), 2.

Gajdzik, B. (2014). Absence management in a manufacturingcompany. Human Resources management, 1(96), 57-71.

Gajdzik, B. (2015). Management of unplanned absences of employees. Organization and Management, 1(29), 39-57.

Kowalska-Jarnot, K. (2015). How employers can reduce the stress of employees? Retrieved from http://nf.pl/kariera/jak-pracodawcy-moga-zmniejszyc-stres-pracownikow,,48420,173

Lis, K. (2015). Retrieved from http://www.miesiecznik-benefit.pl/index.php?wiad=179

Managing absenteeism and motivation of employees. (2014). Retrieved from http://www.hrtrendy.pl/2014/04/11/ zarzadzanie-absencja-motywacja-pracownikow-hr-owcy-spolek-gieldowych-spotkali-sie-raz-trzeci/

Ochremiak, A. (2015). Retrieved from http://www.jobfitter.pl/produkcja/jak-sobie-radzic-z-absencja-pracownicza

Pęcłło, M. (2013). The costs of absenteeism and their reduction. Safety at Work, 10, 13-15.

${ }^{7}$ Retrieved from http://www.employees.pl. 
Rzepecki, J. (2006). Accident prevention in the social accident insurance in selected European countries. Safety at Work, 9, 4-7. Śmid, W. (2000). Lexicon of a manager (p. 9). Cracow: Professional Business School.

Striker, M. (2013). Measurement and analysis of employee absences. Education of Economists and Managers, 3, 99-112.

Szubert, Z., Merecz-Kot, D., \& Sobala, W. (2009). Occupational stress and the risk of sickness absence in customer service positions. Occupational Healthcare, 60(4), 259-271.

The level of absenteeism is growing — how to manage this phenomenon? (2015). Retrieved from http://archiwum.nf.pl/ 19896-poziom-absencji-w-pracy-rosnie-jak-zarzadzac-tym-zjawiskiem/ 